\title{
Behaviorálne intervencie zamerané na zníženie množstva psích exkrementov na verejných priestranstvách: skúsenosti z mesta Hlohovec
}

Behavioural interventions aimed to reduce dog fouling in public areas: experience from the town of Hlohovec

\section{Roman Klimko}

Abstract: The paper focuses on the experiment in the town of Hlohovec in which a behaviouroriented approach is used. The intention is to show that it is possible to solve a dog fouling problem with nudges that are meaningful, low-cost and easy to implement using the behavioural approach. Two interventions are implemented: a pink spray and yellow footprints. The results show that the implementation of the interventions led to a significant reduction in dog faeces left on the ground in a town park. The data show that our results are comparable with other experiments conducted in different countries, can be easily replicated and increase the efficiency of local public policy.

Key words: Dog fouling, Dog walkers. Interventions. Public areas.

JEL Classification: D90. D91.

\section{Úvod}

Článok sa zameriava na terénny behaviorálny výskum (a jeho výsledky) realizovaný v partnerskej samospráve - mesto Hlohovec. Ciel’om príspevku je poukázat' na zistenia, ktoré naznačujú, že behaviorálny prístup vie poskytnút' zmysluplné, l’ahko implementovatel'né a lacné riešenia,čím je možné zvýšit' efektívnost' miestnej samosprávy. V rámci úvodného stretnutia projektového tímu so zástupcami mesta Hlohovec na jeseň 2019 bol identifikovaný problém znečist'ovania verejného priestranstva zo strany psičkárov, a to najmä v parkoch. $\mathrm{Aj}$ napriek tomu, že mesto Hlohovec poskytuje svojim obyvatel'om vrecká na exkrementy, niektorí psičkári ich nepoužívajú a exkrementy po svojich psoch v mnohých prípadoch nezbierajú. Z následnej diskusie vyplynulo, že problém je dlhodobý, rozšírený vo viacerých lokalitách a mesto eviduje množstvo st’ažností zo strany obyvatel'ov. Problém bol identifikovaný ako 
závažný a zároveň riešitel'ný. $\mathrm{Na}$ druhej strane, riešitel'ský tím nedisponoval (a stále nedisponuje) informáciami, že by bola v rámci Slovenska realizovaná behaviorálna intervencia zameraná špecificky na psie exkrementy v parkoch. To len zvýšilo náš záujem o zameranie sa na realizáciu experimentu $\mathrm{v}$ danej oblasti. Navyše, zahraničné zdroje uvádzajú mnoho zdokumentovaných informácií nielen o rozšírenom probléme so psími exkrementmi, ale najmä poskytujú cenný náhl’ad na úspešne zrealizované behaviorálne intervencie v tejto oblasti. Po konzultáciách so zástupcami mesta sme došli k záveru, že vhodným miestom na realizáciu experimentu bude park na ulici R. Dilonga. Ten, aj s ohl'adom na svoju rozlohu, disponuje dostatočným počtom odpadkových košov na zmiešaný odpad. Napriek tomu v danej lokalite niektorí psičkári nezbierajú exkrementy po svojich psoch.

\section{Teoretické východiská}

Znečist'ovanie verejných priestranstiev psími exkrementmi je závažný problém, s ktorým sú konfrontované samosprávy na celom svete. V rámci hlavných dôvodov, prečo je nutné daný problém riešit' je možné identifikovat' a) zdravotné riziká, b) neustále st’ažnosti verejnosti, a c) úsporu nákladov samosprávy na čistenie.

Neodstraňovanie psích exkrementov a ich ponechávanie v parkoch môže mat' vážne zdravotné dôsledky. Riziká sú spojené napríklad s parazitárnym ochorením toxokaróza (a inými závažnými ochoreniami), ktorá sa môže preniest' na človeka aj prostredníctvom psích exkrementov a môže mat' vážne dôsledky na l'udské zdravie (Chen et al., 2018). Prirodzene, najviac ohrozenou skupinou sú deti, ktoré sa pohybujú vol’ne po verejnom priestranstve. V tomto prípade je mimoriadne dôležitou osobná hygiena, čo môže byt' problematické práve pri det'och (Macpherson, 2013). V roku 2005 boli publikované výsledky trojročnej štúdie, v rámci ktorej sa zistilo, že len v Anglicku bolo v uvedenom období zaznamenaných vyše 200000 oficiálnych st’ažností týkajúcich sa psích exkrementov (ENCAMS, 2005). V období rokov 2014 - 2015 samosprávy v Anglicku a Walese zaznamenali 73824 oficiálnych st’ažností zo strany nespokojných občanov, ktorí im komunikovali svoje rozhorčenie nad neupratanými psími exkrementmi na verejných priestranstvách (BBC, 2015). Potreba riešenia problému znečist'ovania verejných priestranstiev psími exkrementmi z dôvodu množstva st'ažností zo strany obyvatel'ov bola identifikovaná aj $\mathrm{v}$ priebehu riešenia sociálneho experimentu organizácie Keep Britain Tidy (2014) v Anglicku v roku 2013. Štúdia Keep Wales Tidy (2016a) tiež považuje množstvo st'ažností za jeden z hlavných dôvodov, pre ktorý je dôležité riešit' problém so psími exkrementmi na verejných priestranstvách. V podmienkach Slovenska sme sa doposial' nestretli s tým, aby si jednotlivé samosprávy viedli špeciálnu evidenciu zameranú 
na počet st'ažností na nájdené psie exkrementy na verejných priestranstvách. Občania však majú možnost' využívat' rôzne komunikačné kanály, prostredníctvom ktorých jednotlivé samosprávy informujú o nájdených psích exkrementoch na verejných (a iných) priestranstvách $\mathrm{v}$ intravilánoch obcí. Problém psích exkrementov je $\mathrm{v}$ rámci slovenských samospráv identifikovatel’ný napríklad aj na stránke https://www.odkazprestarostu.sk, kde môžu občania zaznamenat' svoj podnet. Následné odstraňovania psích exkrementov si vyžaduje alokovanie finančných prostriedkov z rozpočtov samospráv, ktoré by sa dali využit’ na iný zmysluplnejší účel. Pri bližšom pohl'ade na výročné správy mestských polícií v Hlohovci a Bratislave (Hlohovec, 2020; Bratislava, 2020) sa problém so psími exkrementmi na verejných priestranstvách v mestách Hlohovec a Bratislava javí ako takmer neexistujúci. To ale v žiadnom prípade nezodpovedá realite. V správe Waste Improvement Network (Atenstaed a Jones, 2011) sa odhaduje, že samosprávy v Anglicku a Walese míňajú ročne dohromady zhruba 22 miliónov libier na činnosti súvisiace so psími exkrementmi - zber a ukladanie, špeciálne koše, čistenie ulíc, značenie, informačné aktivity pre verejnost' a iné aktivity smerujúce k zmene správania psičkárov. S rovnakým odhadom ročne vynaložených prostriedkov na úrovni 22 miliónov libier na činnosti súvisiace so psími exkrementmi v Anglicku a Walese pracuje aj štúdia Keep Wales Tidy (2016a) z roku 2016.

Riešitel'ský tím považoval vyššie uvedené dôsledky znečist’ovania verejného priestranstva psími exkrementmi za natol'ko významné, že sa domnieval, že je dôležité vyvinút' úsilie s ciel'om zmiernit' problém znečist'ovania verejného priestranstva psími exkrementmi. Skúsenosti zo zahraničia naznačujú, že prostredníctvom nízkonákladových behaviorálnych intervencií je možné výrazným spôsobom znížit' celkový počet psích exkrementov vo vybranej lokalite. Ked’že je problém znečist'ovania verejných priestranstiev psími exkrementmi rozšírený naprieč celým Slovenskom, experiment je replikovatel'ný v ktorejkol’vek samospráve.

\section{Materiál a metódy skúmania}

Hlavným ciel'om experimentu bolo prostredníctvom intervencií zmenit' správanie psičkárov v parku na ulici R. Dilonga v Hlohovci tak, aby sa počet psích exkrementov ponechaných na zeleni v parku znížil o 25 \%. Konkrétne percento, ktoré sme si stanovili, vychádzalo z výsledkov a odporúčaní terénnych experimentov a štúdií realizovaných za účelom zmeny správania psičkárov a zníženia počtu psích exkrementov ponechaných na verejných priestranstvách (BBC, 2012a; BBC, 2012b; BBC, 2013a; BBC, 2013b; Keep Wales Tidy, 2016a; Keep Wales Tidy, 2016b). 
Výber vhodného riešenia mal niekol'ko fáz. Počas úvodného stretnutia projektového tímu so zástupcami mesta Hlohovec na jeseň 2019 bol identifikovaný problém znečist'ovania verejného priestranstva zo strany psičkárov, a to najmä v parkoch. Následne sme sa v prvej fáze výberu vhodného riešenia zamerali na vytvorenie databázy intervencií, ktoré už boli zrealizované inými výskumníkmi v teréne. Čerpali sme zo zahraničných skúseností. V rámci druhej fázy sme vytvorili prehl'ad intervencií, ktoré by sa dali aplikovat' na riešenie problému v meste Hlohovec. Tretia fáza spočívala v prezentácii prehl'adu intervencií zástupcom mesta Hlohovec počas online workshopu v októbri 2020. Počas štvrtej fázy v závere októbra 2020 sme sa so zástupcami mesta Hlohovec dohodli na definitívnej podobe realizovaných intervencií, na finálnom mieste realizácie experimentu - park na ulici R. Dilonga, ako aj na detailnom časovom rámci experimentu. Oblast’ experimentu je znázornená na obrázku 1 svetlozelenou farbou. Pôvodný časový harmonogram bol nastavený tak, že experiment zrealizujeme v priebehu mesiacov marec a apríl (2021). Bohužial', z objektívnych dôvodov zapríčinených pandémiou COVID-19 sme museli realizáciu experimentu posunút' na neskoršie obdobie, konkrétne mesiace jún a júl (2021).

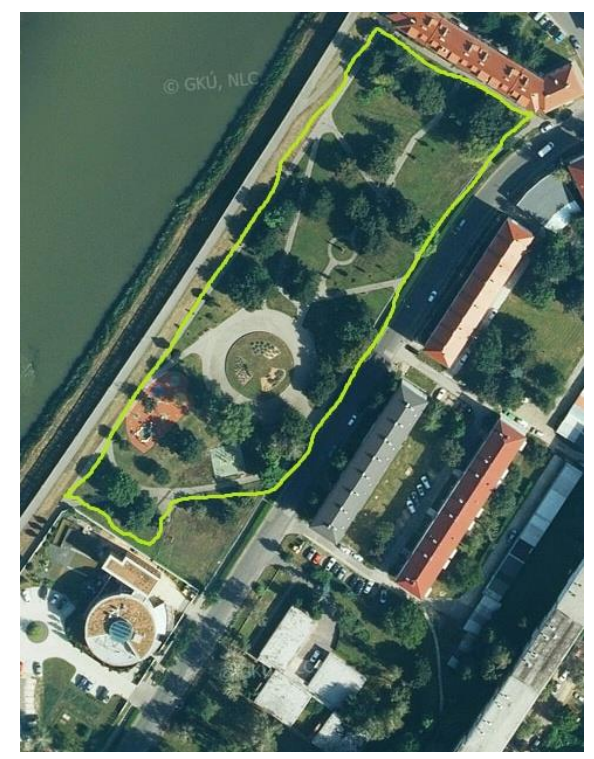

Obrázok 1 Oblast' experimentu

Zdroj: freemap.sk, vlastné spracovanie

Dohodnutá forma intervencií bola realizovaná prostredníctvom dvoch postrčení. Postrčenie 1 spočívalo v aplikácii farebného spreja na exkrementy. Na základe skúseností a odporúčaní autorov štúdií ako aj realizátorov terénnych experimentov (Hansen \& Jespersen, 2013; Keep Britain Tidy, 2015; BBC, 2012a; BBC, 2012b; BBC, 2013a; BBC, 2013b; Keep Wales Tidy, 2016a; Keep Wales Tidy, 2016b) sme sa rozhodli pre využitie ružového spreja, a to pre jeho 
výraznost' a viditel'nost'. Vel'mi dôležité pre experiment na verejnom priestranstve je, že ide o ekologický výrobok, ktorý nepoškodzuje označované predmety, vrátane rastlín, je založený na báze kriedy a l'ahko sa odstraňuje vodou i dažd’om. Výrobca udáva trvanlivost' niekol'ko dní až týždňov, v závislosti od počasia a iných externých vplyvov.

S ciel’om zmeny správania psičkárov využíva postrčenie 1 efekt nápadnosti. Efekt nápadnosti vychádza z použitej jasne ružovej farby, ktorá vytvorí s okolím želaný kontrast a exkrementy budú viditel'né aj z väčšej vzdialenosti. Okrem efektu nápadnosti je experiment v rámci postrčenia 1 založený aj na princípe sociálneho schválenia. Predpokladáme, že jasná viditel'nost' exkrementov spôsobí v l'ud'och zahanbenie, šok, či pobúrenie (BBC, 2012a; BBC, 2012b; BBC, 2013a; BBC, 2013b; Keep Wales Tidy, 2016a; Keep Wales Tidy, 2016b). Následkom toho sa budú snažit' zmenit' či už svoje správanie, alebo (aj) správanie iných.Postrčenie 2bolo realizované počas druhého a tretieho týždňa trvania experimentu v súlade s časovým harmonogramom experimentu uvedeným v tabul'ke 1.

Žlté stopy z reflexnej a protišmykovej (aj vd’aka skleneným gul'ôčkam na povrchu) pásky tvorili postrčenie 2. Stopy nalepené na chodník smerovali k existujúcim odpadkovým košom a zviditel'nili ich. Ciel'om bolo zvýšit' povedomie psičkárov o dostupnosti odpadkových košov v danej lokalite. Aj pri postrčení 2 (rovnako ako pri postrčení 1) využívame efekt nápadnosti. Ten je zabezpečený výraznou žltou, a zároveň reflexnou farbou, čo je dôležité najmä pri zhoršených vizuálnych podmienkach v parku (šero, tma a pod.). Každá stopa je dlhá 297 mm a široká 110 mm, čo zodpovedá približne pánskej topánke vel'kosti UK 11,5. Hrúbka jednej stopy je 1,6 mm. Pri aplikácii stôp sme použili aj podkladový náter odporúčaný pri ich umiestňovaní v exteriéri. Po ukončení realizácie experimentu v súlade $\mathrm{s}$ jeho časovým harmonogramom uvedeným $\mathrm{v}$ tabul'ke 1 sme stopy odstránili a chodník vrátime do pôvodného stavu.

Postrčenie 2 bolo realizované $\mathrm{v}$ súbehu $\mathrm{s}$ postrčením 1 počas tretieho týždňa trvania experimentu v súlade $\mathrm{s}$ jeho časovým harmonogramom uvedeným v tabul'ke 1 . Predpokladali sme, že kombinácia postrčenia 1 a postrčenia 2 zvýrazní vplyv na čistotu parku na ulici R. Dilonga oproti stavu pred ňou.

Pri tomto experimente je mimoriadne dôležité zohl'adnit', v čo možno najväčšej miere, potenciálny vplyv počasia, ktoré je špecifické v rôznych ročných obdobiach. Môže výrazným spôsobom ovplyvnit', alebo až znemožnit' monitorovanie, implementáciu intervencií, či zber dát. Následkom toho by mohlo dôjst' k nutnosti prerušenia experimentu, jeho presunutia na iný termín so začiatkom úplne odznova, či prípadnej nemožnosti vyhodnotenia zozbieraných dát. Preto sme sa snažili byt' pri zostavovaní časového harmonogramu (tabul'ka 1) mimoriadne dôslední a využit’ doterajšie skúsenosti z experimentov realizovaných v zahraničí. Najskôr sme 
vylúčili zimné mesiace, kedy je venčenie psov z dôvodu počasia relatívne limitované. Predpokladáme, že v zimnom období sa majitelia psov snažia čo najviac obmedzit' svoj pobyt v chladnom prostredí a skôr budú venčit’ psov len v okolí svojich domov, resp. bytov. Sneženie a následná snehová pokrývka by mohla znemožnit' identifikáciu exkrementov. V jesennom období sa v slovenských podmienkach často stretávame s neodhrabaným lístím na verejných priestranstvách, ktoré by prikrylo prípadné exkrementy a zmarilo zber dát. Z hl'adiska monitorovania, zberu údajov a implementácie experimentov sú najvhodnejšie jarné a letné mesiace, čo je v súlade so zisteniami a odporúčaniami štúdie Keep Britain Tidy (2015). Z nej tiež vyplýva, že najväčším problémom je vybrat' vhodné obdobie na realizáciu experimentu, lebo v rámci každého mesiaca v roku môžeme byt' konfrontovaní s rôznymi neštandardnost’ami, ako prázdniny a pod. Napríklad aj letné prázdniny patria medzi obdobie, v ktorom sa bežné zvyklosti l'udí menia, môžu byt' odcestovaní a pod.

Na základe výsledkov štúdií a skúseností z ich realizácie (Blenderman et al., 2018; Keep Britain Tidy, 2015; Lowe et al., 2014) sme sa pôvodne rozhodli experiment uskutočnit' v mesiacoch marec a apríl (2021), kedy sa predpokladajú najvhodnejšie podmienky na realizáciu experimentu. V tomto období je zvyčajne stav zelene v parkoch na Slovensku vhodný na pomerne jednoduchú identifikáciu psích exkrementov. Avšak, situácia spojená s pandémiou COVID-19 nám neumožnila pristúpit' $\mathrm{k}$ realizácii experimentu $\mathrm{v}$ jarných mesiacoch. Experiment sa po konzultáciách riešitel'ského tímu so zástupcami mesta Hlohovec realizoval v parku na ulici R. Dilonga od 15. júna 2021 do 6. júla 2021. Pri výbere definitívneho termínu sme zvažovali rozličné pozitíva a negatíva. V rámci uvažovania sme vzali do úvahy aj zistenia a odporúčania vyplývajúce $\mathrm{z}$ už úspešne realizovaných experimentov v zahraničí. Konkrétne, v meste Conwy (Wales) sa v rámci realizácie experimentu zameraného na zmenu správania psičkárov zistilo, že l’udia vnímajú zvýšené množstvo na zemi nechaných psích exkrementov počas prázdnin (Keep Wales Tidy, 2016b). V porovnaní so školským rokom sa počas prázdnin v parkoch vo všeobecnosti predpokladá zvýšený pohyb osôb, a najmä detí. Realizácia experimentu práve na prelome júna a júla môže mat' výraznejší spoločenský význam pre celú komunitu v rámci mesta Hlohovec. Aj ked' si riešitel'ský tím uvedomuje, že letné mesiace môžu mat' vplyv na zvýšený počet nájdených psích exkrementov v parku, pôvodný ciel' zníženia počtu psích exkrementov nájdených v parku ostáva nezmenený, a to na úrovni $25 \%$.

Časový harmonogram experimentu bol rozvrhnutý na tri týždne (tabul'ka 1). 
Tabul'ka 1 Časový harmonogram experimentu

\begin{tabular}{|c|c|c|c|}
\hline Fáza & Aktivity & Vykonáva(jún) & Časový rámec \\
\hline 1 & $\begin{array}{c}\text { Vytvorenie a doladenie } \\
\text { experimentálneho dizajnu }\end{array}$ & $\begin{array}{c}\text { Autor a zástupcovia } \\
\text { mesta Hlohovec }\end{array}$ & december 2020 - február 2021 \\
\hline 2 & $\begin{array}{c}\text { Monitorovanie } \\
\text { počiatočného stavu }\end{array}$ & Riešitel'ský tím & 15.6. 2021-22.6.2021 \\
\hline 3 & $\begin{array}{c}\text { Implementácia } \\
\text { Postrčenia 1 + zber dát }\end{array}$ & Riešitel'ský tím & 22.6.2021 - 29.6. 2021 \\
\hline 4 & $\begin{array}{c}\text { Implementácia } \\
\text { Postrčení 1 a 2 + zber dát }\end{array}$ & Riešitel'ský tím & 29.6. 2021 - 6. 7. 2021 \\
\hline 5 & $\begin{array}{c}\text { Vyhodnotenie } \\
\text { zozbieraných dát }\end{array}$ & Riešitel'ský tím & júl - august 2021 \\
\hline 6 & $\begin{array}{c}\text { Prezentácia výsledkov a } \\
\text { odporúčaní (workshop) }\end{array}$ & Riešitel'ský tím & september 2021 \\
\hline
\end{tabular}

Zdroj: autor

Pôvodným zámerom bolo realizovat' zber dát o počte psích exkrementov, ako aj aplikáciu ružového spreja, na zeleni v parku do vzdialenosti približne 3 metrov od okrajov na oboch stranách chodníka. Na základe štúdie realizovanej v Anglicku (Lowe et al., 2014) sú práve 3 metre optimálne, berúc do úvahy viditel'nost' exkrementu z chodníka. Avšak s ohl'adom na oblast' experimentu sme po konzultáciách so zástupcami mesta Hlohovec dospeli k záveru, že experiment bude prebiehat' $\mathrm{v}$ rámci celého parku. To znamená, že nebudeme limitovaní tromi metrami po oboch stranách chodníka. Medzi dôvodmi, prečo sme sa tak rozhodli, je aj poloha chodníkov, pozorované hlavné smery pohybu chodcov $\mathrm{v}$ rámci parku, prítomnost' streetworkoutového, a najmä detského ihriska a iné. Predovšetkým pohyb detí a mládeže okolo ihrísk bol počas pozorovania vel'mi rozmanitý a v rámci parku nebol obmedzený len na chodníky.

Dáta zbierali členovia riešitel'ského tímu v dňoch 15. 6., 22. 6., 29. 6. a 6. 7. 2021 podl'a časového harmonogramu uvedeného v tabul'ke 1. Presné polohy nájdených psích exkrementov sú zaznamenané v dňoch 15. 6., 22. 6., 29. 6. a 6. 7. 2021. Týmto spôsobom je zabezpečený prehl'ad o pôvodných a nových psích exkrementoch $\mathrm{v}$ parku. $\mathrm{V}$ rámci monitorovania počiatočného stavu riešitel'ský tím zmapoval prírastok psích exkrementov v období 15. 6. 2021 - 22. 6. 2021. V d’alších fázach realizácie experimentu sú prírastky psích exkrementov zaznamenané v obdobiach 22. 6. 2021 - 29. 6. 2021 a 29. 6. 2021 - 6. 7. 2021. Dňa 22. 6. 2021 
sa pristúpilo $\mathrm{k}$ implementácii postrčenia 1 a dňa 29. 6. $2021 \mathrm{k}$ implementácii postrčenia $1 \mathrm{v}$ súbehu s postrčením 2 (znázornené na obrázku 2).

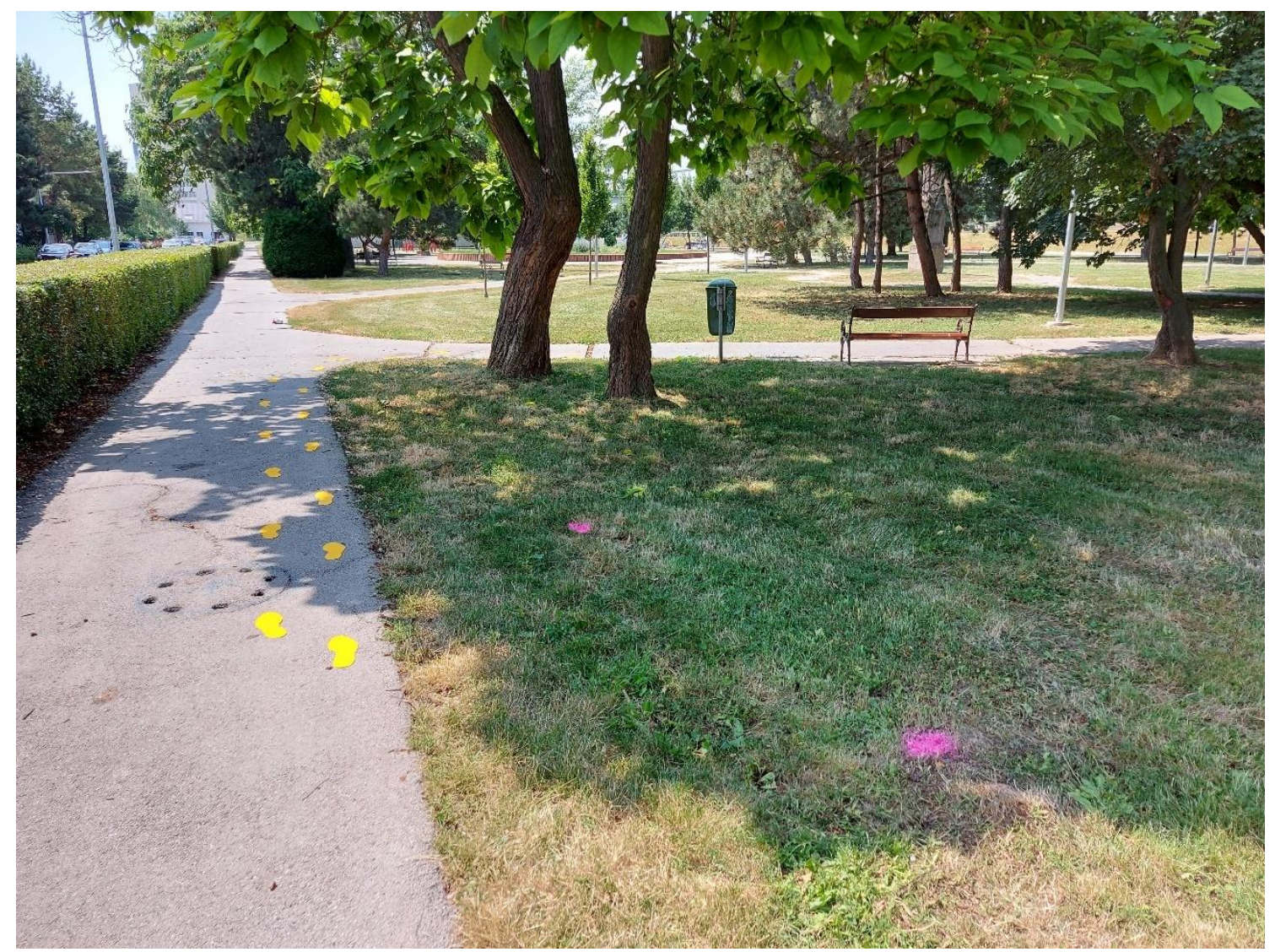

Obrázok 2 Príklad implementácie postrčenia 1 v súbehu s postrčením 2

Zdroj: autor

\section{Výsledky a diskusia}

Implementáciou intervencií (postrčenie 1 a postrčenie 2) sa v sledovanom období znížil počet psích exkrementov ponechaných na zeleni v parku o 40,9\%. Hlavným cielom experimentu bolo prostredníctvom intervencií zmenit' správanie psičkárov v parku na ulici R. Dilonga v Hlohovci tak, aby sa počet psích exkrementov ponechaných na zeleni v parku znížil o 25 \%. Konštatujeme, že ciel' sa podarilo splnit'. V rámci monitorovania počiatočného stavu sme identifikovali celkovo 22 psích exkrementov a v priebehu konečného zberu dát sme našli 13 psích exkrementov ponechaných na zeleni v parku (graf 1). V grafe 1 predstavuje sivý stípec (Ciel') ciel’ovú hodnotu zníženia o $25 \%$ absolútna hodnota 16,5 psích exkrementov.

Zahraničné štúdie, ktoré obsahujú výsledky podobných terénnych experimentov zameraných na znečist'ovanie verejných priestranstiev psími exkrementmi s konkrétnymi údajmi o ich účinnosti vyplýva, že účinnost' sa $\mathrm{v}$ ich rámci pohybuje od $49 \%$ do $72 \%$ 
(Huffington Post, 2013; Keep Britain Tidy, 2015; BBC, 2012a; BBC, 2012b; BBC, 2013a; BBC, 2013b; Keep Wales Tidy, 2016a; Keep Wales Tidy, 2016b). V iných štúdiách nebol konkrétny údaj o účinnosti realizovaných intervencií vyčíslený a konštatovalo sa len výrazné, resp. významné zníženie počtu nájdených psích exkrementov na verejných priestranstvách (My London, 2019; Newsweek, 2021; Somerset Live, 2021).

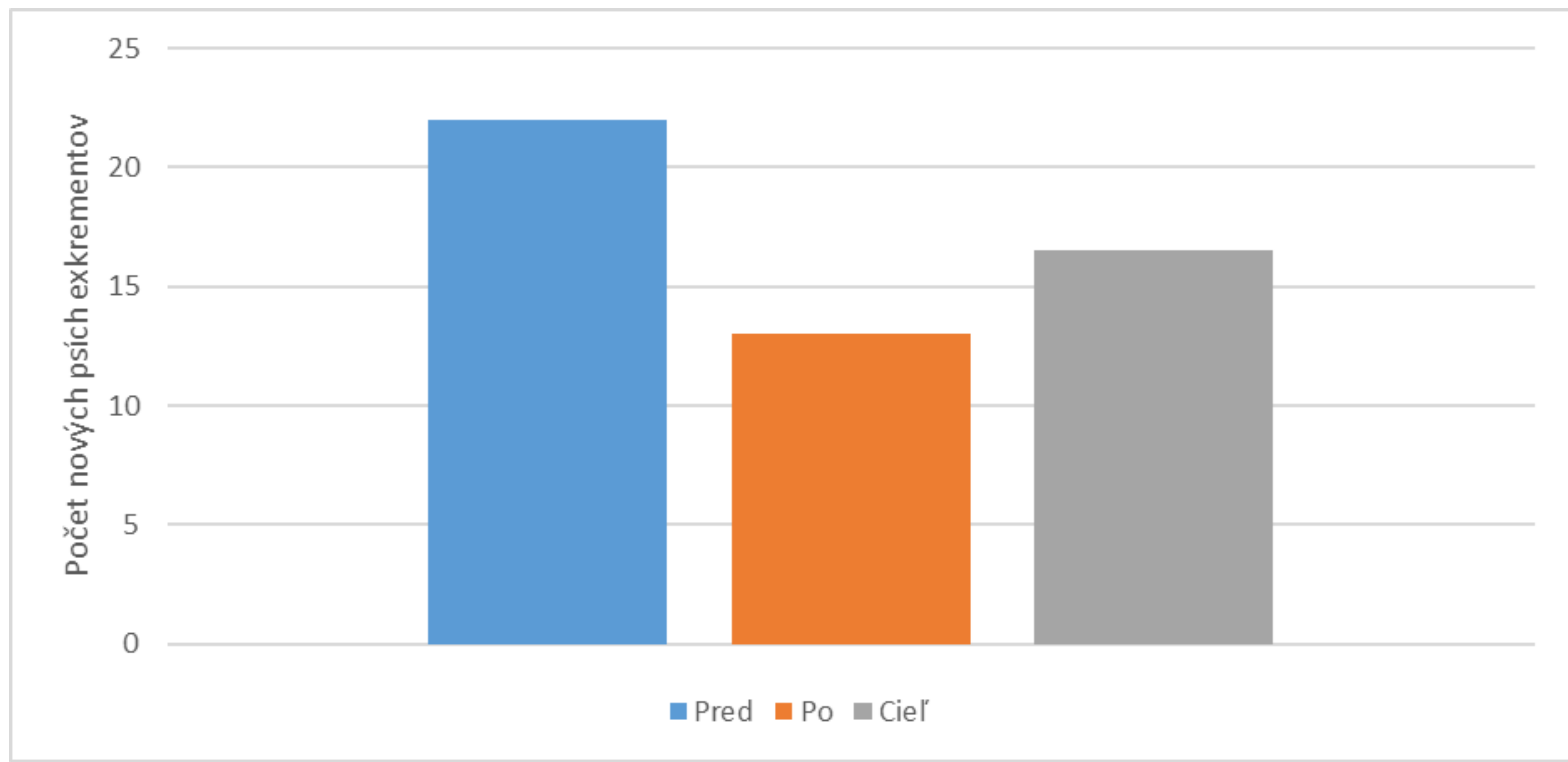

Graf 1 Efekt zavedenia oboch intervencií na počet nájdených psích exkrementov Zdroj: autor

Z hl'adiska čiastkových krokov sme postupovali podl'a časového harmonogramu uvedeného v tabul'ke 1. Dňa 22. 6. 2021 sme realizovali postrčenie 1 formou aplikácie ružového spreja na psie exkrementy. Dňa 29. 6. 2021 sme implementovali postrčenie $1 \mathrm{v}$ súbehu s postrčením 2, teda sme použili ružový sprej v spojení s aplikáciou žltých stôp.

Pri aplikácii ružového spreja i žltých stôp sme využívali skúsenosti z podobných experimentov realizovaných v zahraničí, aby sme sa dopracovali k čo najlepším výsledkom. Použili sme vysokokvalitný biodegradovatel'ný sprej, ako aj odolné, dobre viditel'né a protišmykové stopy. Zo zistení zaznamenaných počas experimentu vyplýva, že sme neidentifikovali žiadne poškodenia na chodník nalepených stôp a preto môžu byt' využívané aj v priebehu dlhšieho časového obdobia, čo má pozitívny vplyv na náklady. Ružový sprej bol aj po siedmich dňoch dobre viditel'ný a tým pádom plnil svoju funkciu. Tu však zdôrazňujeme, že v priebehu realizácie experimentu neboli v danej oblasti zaznamenané takmer žiadne zrážky. V prípade daždivejšieho obdobia odporúčame sprej aplikovat' častejšie. Z hl'adiska výberu ročného obdobia sme tiež čerpali zo zahraničných skúseností a môžeme konštatovat', že prelom júna a júla sa ukázal ako správne rozhodnutie. Monitorovanie počiatočného stavu, 
implementácia postrčení, ako aj zber dát prebiehali bez problémov. S ohl'adom na množstvo listnatých stromov v parku na ulici R. Dilonga by na realizáciu experimentu pripadali ešte do úvahy jarné mesiace. Naopak, na jeseň by bol experiment len vel'mi t’ažko realizovatel'ný, a to vzhl'adom na množstvo opadaného lístia na zemi. Tu však chceme zdôraznit', že každá lokalita je jedinečná a vždy treba $\mathrm{k}$ jej výberu pristupovat' mimoriadne citlivo, a to až po dôkladnom zvážení všetkých potenciálnych vplyvov priamo na mieste.

Po aplikácii postrčenia 1 a jeho následnom vyhodnotení priamo na mieste sa riešitel'ský tím rozhodol pre aplikáciu postrčenia 2 v lokalite, $v$ rámci ktorej došlo $\mathrm{k}$ výraznému nárastu nájdených psích exkrementov po aplikácii ružového spreja. V ostatných najexponovanejších lokalitách bol po aplikácii postrčenia 1 zaznamenaný významný pokles (resp. žiadne) nájdených psích exkrementov.

Z hl'adiska odporúčaní pre samosprávu si myslíme, že by bolo vhodné osadit' odpadkové koše $\mathrm{v}$ mestskom parku rovnomernejšie, čo by mohlo prispiet' $\mathrm{k}$ úbytku nájdených psích exkrementov. Celkový počet odpadkových košov (7), ktoré sa v súčasnosti v parku nachádzajú, by za určitých okolností mohol byt' dostatočný. Ich rozmiestnenie však nie je ani zd’aleka optimálne. Jedným z riešení zviditel’nenia odpadkových košov by mohlo byt' aj dlhodobé používanie odolných a protišmykových stôp nasmerúvajúcich psičkárov k odpadkovým košom. Výsledky experimentu preukázali, že aplikácia ružového spreja na psie exkrementy prispela $\mathrm{k}$ významnému zníženiu počtu nájdených psích exkrementov v parku na ulici R. Dilonga. Na základe toho si myslíme, že by to mohol byt' spôsob, ako dosiahnut' dlhodobo nízke počty psích exkrementov v parku pri minimálnych nákladoch.

Samozrejme, ideálne by bolo experiment realizovat' v dlhšom časovom období, resp. sledovat', či pozitívna zmena správania psičkárov je dlhodobá. Avšak, súčasná doba nepraje plánovaniu v dlhšom časovom horizonte. Presvedčili sme sa o tom aj sami, ked' sme z dôvodu obmedzení súvisiacich s pandémiou COVID-19 museli experiment presunút' z jarných na letné mesiace. Aj napriek tomu bolo potrebné rátat' s prípadnými náhlymi a nepredvídatel'nými novými obmedzeniami a opatreniami, či zmenami už existujúcich obmedzení a protipandemických opatrení. Tie našt’astie počas celej doby trvania experimentu nenastali a experiment prebehol podl'a naplánovaného časového harmonogramu. Relatívne krátke obdobie trvania experimentu však s ohl'adom na ciel'ovú skupinu a jeho nastavenie nepovažujeme za problematické. Venčenie psov je totiž pravidelne sa opakujúca činnost'. Navyše, ako sme už vyššie spomínali, počasie experimentu mimoriadne prialo. V rámci budúcich úspešných experimentov v danej oblasti odporúčane nepodcenit' dôkladnú prípravu a mat' pripravené rôzne alternatívy. Potrebné je tiež rátat' s tým, že exkrementy by sa mohli vplyvom aplikácie 
intervencií vo zvolenej lokalite presunút' do iných lokalít, pril’ahlých ulíc a podobne. V rámci riešitel'ského tímu sme sa toto možné skreslenie snažili minimalizovat' tým, že sme si pre realizáciu experimentu, po dohode so zástupcami mesta Hlohovec, zvolili celý park a nie len jeho čast'. Ako je už spomenuté vyššie, po aplikácii postrčenia 1 došlo od 22. 6. 2021 do 29. 6. 2021 k nárastu počtu nájdených psích exkrementov v špecifickej časti parku, v ktorej bol ružový sprej aplikovaný dňa 22. 6. 2021 len minimálne.

\section{Záver}

Experimentom v oblasti riešenia problému exkrementov psov v parkoch sme preukázali, že aj v slovenských podmienkach je možné realizovat' nízkonákladové behaviorálne intervencie s výsledkami porovnatel'nými so zahraničím. Veríme, že naša pozitívna skúsenost' z Hlohovca podnieti aj d’alších výskumníkov, aby participovali na obdobných typoch projektov. Tým pomôžu samosprávam naprieč celým Slovenskom zlepšit’ životné prostredie ako aj subjektívnu spokojnost' so životom na lokálnej úrovni pre všetkých svojich obyvatel'ov.Na druhej strane, tento článok je tiež jednoduchým a praktickým návodom na realizáciu podobného experimentu aj v rámci interných personálnych kapacít v ktorejkol’vek samospráve na Slovensku.

Musíme zdôraznit', že počas celého procesu súvisiaceho s plánovaním, prípravou a realizáciou experimentu bola spolupráca $\mathrm{s}$ mestom Hlohovec na vysokej úrovni a v rámci projektového tímu sme cítili vel'kú podporu. Pravdepodobne to vyplynulo aj z toho, že prvotný impulz realizovat' intervenciu s ciel'om znížit' rozsah znečist’ovania verejných priestorov psími exkrementmiprišiel od zástupcov mesta Hlohovec. Odporúčame preto, aby sa obdobný prístup stal štandardom, čo sa javí ako predpoklad pre úspešnú spoluprácu s ciel’om dosiahnut' čo najlepšie výsledky.V súčasnosti však, aj s ohl'adom na pretrvávajúcu nepriaznivú situáciu spojenú s pandémiou COVID-19 a mnohé pre samosprávu náročné, nepredvídatel'né a nárazové úlohy s tým spojené, mesto Hlohovec neplánuje v blízkej budúcnosti realizovat' behaviorálne intervencie zamerané na psie exkrementy vo vlastnej réžii.

Grantová podpora: Príspevok bol pripravený s podporou projektu VEGA 1/0239/19 Implikácie behaviorálnej ekonómie pre zefektívnenie fungovania súčasných ekonomík a projektu APVV-18-0435 Behaviorálne intervencie v miestnej samospráve: zvyšovanie účinnosti miestnych verejných politík. 


\section{Zoznam použitej literatúry}

[1] Atenstaedt, R. L., \& Jones, S. (2011). Interventions to preventdogfouling: a systematicreview of evidence. [Zásahy na zabránenie znečisteniu psom: systematické preskúmanie dôkazov]. PublicHealth, 125(2), 90-92.

[2] BBC. (2012a). Dog mess to be spray-painted pink by West Dunbartonshire Council. [Neporiadok od psov bude nastriekaný na ružovo od West Dunbartonshire Council]. Dostupné na stránke BBC: Dostupné na: https://www.bbc.com/news/uk-scotland-glasgowwest-18598092

[3] BBC. (2012b). Spray-painting reduces dog fouling by almost three-quarters. [Striekanie znižuje znečistenie od psov takmer o tri štvrtiny]. Dostupné na stránke BBC: https://www.bbc.com/news/uk-england-berkshire-19064119

[4] BBC. (2013a). Boston Council 'flagsup' dog dirt to shame pet owners. [Boston Council 'flagsup' psie nečistoty na hanbu majitel'ov domácich zvierat] Dostupné na stránke BBC: https://www.bbc.com/news/uk-england-lincolnshire-22691529

[5] BBC. (2013b). Eight radical solutions to the problem of dog mess. [Osem radikálnych riešení pre problémy so psím neporiadkom]. Dostupné na stránke BBC:https://www.bbc.com/news/magazine-22853270

[6] BBC. (2015). Dog poo fines 'down by almost $20 \%$ in England and Wales'. [Pokuty za psie výkaly „, Anglicku a Walese klesli takmer o 20 \%“]. Dostupné na stránke BBC: https://www.bbc.com/news/uk-33064119

[7] Blenderman, A., Taff, B. D., Schwartz, F., \& Lawhon, B. (2018). Dog Guardians' Perceptions and Behaviors Related to the Disposal of Pet Waste in City of Boulder Open Space and Mountain Parks. [Vnímanie a správanie psích strážcov súvisiace s likvidáciou odpadu domácich zvierat v otvorenom priestore mesta Boulder a horských parkoch]. Final Report preparedfor City of Boulder, Colorado, OpenSpace and MountainParks by Pennsylvania State University and theLeave No Trace Center forOutdoorEthics.

[8] Bratislava. (2020). Správe o plnení úloh Mestskej polície hlavného mesta Slovenskej republiky Bratislavy za rok 2019. Dostupné na stránke mesta Bratislava: https://zastupitelstvo.bratislava.sk/data/att/46721.pdf

[9] ENCAMS. (2005). Control of Dogs Survey 2005/06. [Prieskum kontroly psov 2005/06]. Dostupné na stránke Keep Britain Tidy: http://www.keepbritaintidy.org/ImgLibrary/dogfouling_control_dogs_survey_639.pdf 
[10] Hansen, P. G., \& Jespersen A. M. (2013). Nudge and the Manipulation of Choice: A Frame work for the Responsible Use of the Nudge Approach to Behaviour Change in Public Policy. [Postrčenie a manipulácia vol'by: Rámec pre zodpovedné používanie prístupu postrčenia k zmene správania vo verejnej politike.]. European Journal of Risk Regulation, 4(1), 3-28.

[11]Hlohovec. (2020). Správa o činnosti Mestskej polície Hlohovec za rok 2019. Dostupné na stránke mesta Hlohovec:https://www.hlohovec.sk/download_file_f.php?id=1393325

[12]Huffington Post. (2013). Town Mails Dog Poop Back To Negligent Owners In Spain. []. Dostupné na Huff Post: https://www.huffpost.com/entry/town-mails-dog-poopspain_n_3390191?utm_hp_ref=world\&_guc_consent_skip=1596027816\&guccounter=1

[13]Chen, J., Liu, Q., Liu, G. H., Zheng, W. B., Hong, S. J., Sugiyama, H., Zhu, X. Q., \& Elsheikha, H. M. (2018). Toxocariasis: a silent threat with a progressive public health impact. [Toxokaróza: tichá hrozba s progresívnym dopadom na verejné zdravie]. InfectiousDiseases of Poverty, 7(1), 1-59.

[14] KeepBritainTidy. (2014). Keeping an eye on it: A social experiment to combat dog fouling. [Dávajte si na to pozor: Sociálny experiment na boj proti znečisteniu psov]. Dostupné na stránke Keep Britain Tidy: https://www.keepbritaintidy.org/sites/default/files/resource/Keeping\%20an\%20eye\%20o n\%20it_Final\%20report.pdf

[15] KeepBritainTidy. (2015). Green Footprints: An experiment to nudge people towards responsible litter disposal. [Zelené stopy: Experiment, ktorý má l’udí postrčit' $\mathrm{k}$ zodpovednej likvidácii odpadu]. Dostupné na Keep Britain Tidy: https://www.keepbritaintidy.org/sites/default/files/resources/KBT_CFSI_Green_Footprin ts_Report_2015.pdf

[16] Keep Wales Tidy. (2016a). Dog fouling: a review of interventions. [Znečistenie od psov: prehl'ad zásahov]. Dostupné na stránke Keep Wales Tidy: https://www.keepwalestidy.cymru/Handlers/Download.ashx?IDMF=8e88b9f0-cd984162-8dd0-b5cf995c7d2d

[17] Keep Wales Tidy. (2016b). Tackling dog fouling through social marketing: a trial by Keep Wales Tidy. [Riešenie znečistenia psov prostredníctvom sociálneho marketingu: skúška od Keep Wales Tidy]. Dostupné na stránke Keep Wales Tidy: https://www.keepwalestidy.cymru/Handlers/Download.ashx?IDMF=2bf9b2bd-8b41$492 c-a b 18-223 a 933794 c 9$ 
[18]Lowe, C. N., Williams, K. S., Jenkinson, S., \& Toogood, M. (2014). Environmental and social impacts of domestic dog waste in the UK: investigating barriers to behavioural change in dog walkers. [Environmentálne a sociálne vplyvy domáceho psieho odpadu v Spojenom královstve: skúmanie prekážok zmeny správania u psovodov]. International Journal of Environment and Waste Management, 13(4), 331-347.

[19] Macpherson, C.N. (2013). The epidemiology and public health importance of toxocariasis: a zoonosis of globalimportance. [Epidemiológia a význam toxokarózy pre verejné zdravie: zoonóza globálneho významu]. International Journal forParasitology, 43(12-13), 9991008.

[20] MyLondon (2019). People in Brixton are spray painting dog poo pink. [L'udia v Brixtone sprejujú psie hovienka na ružovo]. Dostupné na My London https://www.mylondon.news/news/south-london-news/people-brixton-spray-painting$\operatorname{dog}-16269442$

[21]Newsweek (2021). Town Volunteers Spray Paint Ditched Dog Feces Pink to Shame Owners. [Mestskí dobrovol’níci nastriekajú ružové výkaly zakopaných psov, aby zahanbili majitel'ov]. Dostupné na Newsweek: https://www.newsweek.com/town-volunteers-spraypaint-ditched-dog-feces-pink-shame-owners-1581364

[22] Somerset Live (2021). Bath community group sprays dog poo pink to highlight 'extreme' level of mess at park. [Skupina komunity Bath sprejuje psie trus ružovou farbou, aby zvýraznila „extrémnu“ úroveň neporiadku v parku]. Dostupné na Somerset Live: https://www.somersetlive.co.uk/news/local-news/bath-community-group-sprays-dog5193319

Adresa autorov: Ing. Roman Klimko, PhD., Katedra sociálneho rozvoja a práce, Národohospodárska fakulta, Ekonomická univerzita v Bratislave, Dolnozemská cesta 1, 85235 Bratislava, Slovenská republika, roman.klimko@euba.sk 